\title{
AUDIODESCRIÇÃO NO TELEJORNALISMO: A INCLUSÃO DAS PESSOAS COM DEFICIÊNCIA VISUAL POR MEIO DA DESCRIÇÃO DAS IMAGENS
}

\author{
Audiodescription in telejournalism: the inclusion of people with visual deficiency \\ through the description of the images
}

\begin{abstract}
Audiodescripción en el telejornalismo: la inclusión de las personas con discapacidad visual por medio de la descripción de las imágenes
\end{abstract}

Kelly Scoralick ${ }^{*}$

\begin{abstract}
Resumo
A audiodescrição (AD) é um recurso de acessibilidade comunicacional que beneficia as pessoas cegas ou com baixa visão. Consiste na descrição das imagens do que está sendo apresentado. A pesquisa busca abordar o uso da audiodescrição no telejornalismo como forma de incluir as pessoas com deficiência visual na televisão. Para a pesquisa foram apresentadas as possibilidades de inserção da AD no telejornalismo, como exemplo, no MGTV, telejornal transmitido pela TV Integração, afiliada da Rede Globo em Juiz de Fora, Minas Gerais. A investigação conclui que a AD é funcional no telejornalismo, fazendo com que as pessoas cegas ou com baixa visão possam acompanhar o que está sendo exibido sem perda de informação. Desde o nome do entrevistado aos trajes e características físicas dos apresentadores e convidados, na movimentação de cena no estúdio e em sobe som de reportagens, assim como é fundamental a $\mathrm{AD}$ das vinhetas e de gráficos que são utilizados em alguns momentos. O estudo traz ainda novas perspectivas para o ensino do telejornalismo nas universidades.
\end{abstract}

PALAVRAS-CHAVE: Audiodescrição. Telejornalismo. Pessoas com Deficiência Visual

\begin{abstract}
Audio description (AD) is a communicational accessibility tool that benefits blind and low-vision people. It's based on the description of what are being showed on the screen. The research to address the use of audiodescription in telejournalism as a way to include visually impaired people in television. For the research the possibilities of insertion of the $\mathrm{AD}$ in the telejournalism were presented, like example, in MGTV, television newscast transmitted by the TV Integração, affiliate of Rede Globo in Juiz de Fora, Minas Gerais. The research concludes that AD is functional on television in all genres covered, making blind or low-vision people able to monitor what is being displayed on TV without loss of information. From the name of the interviewed people to the costumes and physical characteristics of the anchorman or anchorwoman and guests, in the scene movement in the studio and in the sound of reports, just as it is fundamental to the $\mathrm{AD}$ of the vignettes and graphics that are used in some moments. The study also presents new perspectives for the teaching of telejournalism in universities.
\end{abstract}

KEYWORDS: Audiodescription. Telejournalism. Visual Impairment People

*Doutora em Comunicação pela Universidade Federal do Rio de Janeiro (UFRJ). Especialista em Audiodescrição e Mídia e Deficiência pela Universidade Federal de Juiz de Fora (UFJF). Especialista em Tradução Audiovisual Acessível/Legendagem pela Universidade Estadual do Ceará (UECE). Professora nos cursos de Jornalismo e Publicidade e Propaganda do Centro de Ensino Superior de Juiz de Fora (CES/JF). Endereço: Av. Luz Interior, 345, Estrela Sul. Juiz de Fora/MG. E-mail: scoralickkelly@ gmail.com 


\section{Resumen}

La audiodescripción (AD) es un recurso de acessibilidade comunicacional que beneficia a las personas ciegas o com baja visión. Consiste en la descripción de las imágenes de lo que se está presentando. La investigación busca abordar el uso de la audiodescripción en el periodismo televisivo como forma de incluir a las personas con discapacidad visual em la televisión. Para la investigación se presentaron las possibilidades de inserción de la $\mathrm{AD}$ en el telediario, com ejemplo, en el MGTV telediario transmitido por la TV Integração, afiliada de la Rede Globo en Juiz de Fora, Minas Gerais. La investigación concluye que la $\mathrm{AD}$ es funcional en el telediario, haciendo que las personas ciegas o com baja visión puedan acompanhar lo que está siendo exhibido sin perdida de información. Desde el nombre del entrevistado a los trajes y características físicas de los presenteadores e invitados, en el movimento de escena en el estúdio y en sobe sonido de reportajes, así como es fundamental la AD de las viñetas y de gráficos que se utilizan em algunos momentos. El estúdio trae aún nuevas perspectivas para la enseñanza del telediario en las universidades.

PALABRAS CLAVE: Audiodescripción. Periodismo Televisivo. Personas con Discapacidad Visual.

\section{INTRODUÇÃO}

Estabelecer um novo olhar para as pessoas com deficiência. Buscamos apresentar um mundo que poucos enxergam, uma minoria marginalizada - distante de seus direitos e até com pouco conhecimento sobre eles. Estima-se que $10 \%$ da população mundial têm algum tipo de deficiência, segundo dados da Organização Mundial de Saúde. Deste total, 2\% apresentam deficiência visual. No Brasil, de acordo com o Censo 2010, feito pelo Instituto Brasileiro de Geografia e Estatística (IBGE), 23,9\% da população têm alguma deficiência seja física, mental, auditiva ou visual - totalizando quase 45 milhões de pessoas. Neste levantamento a deficiência visual apresentou o maior índice, ocorrendo em 18,6\% da população. Essa parcela vive uma exclusão não somente social como intelectual e cultural.

A tentativa é de incluí-los em uma sociedade também ainda pouco ciente de seus deveres, uma sociedade que cria leis para tentar fazer valer os direitos dessa minoria, mas que ainda assim tem pouca consciência da importância deles. Esse artigo aborda a inclusão dessas pessoas por meio do uso da audiodescrição (AD), a descrição das imagens para aqueles que não podem percebê-las. Uma abordagem recente, repleta de ganhos. O público a ser incluído é de pessoas com deficiência visual, sejam cegos ou com baixa visão. Mas as AD vem trazendo benefícios para outros tantos visitantes, leitores, ouvintes e telespectadores, no teatro, no espetáculo de dança, musicais, nas histórias em quadrinhos, em palestras, no museu, no cinema, no DVD que se assiste em casa e na TV e em muitos outros espaços e ambientes.

A oferta da audiodescrição vem chegando aos poucos. No país o recurso já é obrigatório na TV desde julho de 2011, seguindo determinação da Portaria no 188, de 25 de março de 2010 (BRASIL, 2010), que estabeleceu um cronograma para inserção da audiodescrição na programação. Inicialmente a obrigatoriedade era por duas horas semanais de programação com AD. E deve atingir 20 horas semanais em um prazo de 10 anos, a contar da data da publicação da portaria, prazo que se encerra em julho de 2020. Portanto, o tempo máximo de exigência do recurso na TV de acordo com critério estabelecido pela portaria é de 20 horas. No entanto, a AD na televisão ainda aparece em poucos programas, basicamente em 
filmes e séries, mas também disponível em alguns programas infantis, educativos, religiosos, revistas e em uma novela, segundo levantamento realizada por essa pesquisadora (SCORALICK, 2017). Essa pesquisa, portanto, visa demonstrar a importância da audiodescrição na televisão na inclusão das pessoas com deficiência visual, apresentando as possibilidades de inserção da $\mathrm{AD}$ no telejornalismo, meio de informação de milhões de pessoas. Dentre essa fatia estão também os cegos e pessoas com baixa visão, que querem acompanhar as notícias e saber os detalhes das imagens que estão sendo apresentadas na tela. Buscamos desvendar os espaços no telejornal onde as narrações são possíveis de serem encaixadas com as informações audiodescritas.

Foi realizado um levantamento (SCORALICK, 2017), no portal de teses da Coordenação de Aperfeiçoamento de Pessoal de Nível Superior (Capes) ${ }^{1}$, e também no banco de teses do Instituto Brasileiro de Informação em Ciência e Tecnologia (IBICT) ${ }^{2}$. Cientes da diferença de grafia utilizada por alguns estudiosos da área, sendo áudio-descrição, com hífen, e outros preferem audiodescrição, sem hífen e sem acento, fizemos duas buscas em cada banco. Os temas nas pesquisas com audiodescrição encontrados estão voltadas basicamente para as áreas de cinema, TV digital, na publicidade, teatro e desenho para crianças, nos musicais, nas artes, seja na dança ou na acessibilidade nos museus, no uso em imagens estáticas, na área da educação, e ainda em eventos, como o uso da AD nos desfiles das escolas de samba ou em uma partida de futebol. Conforme o levantamento, não há nenhuma menção da utilização da audiodescrição no telejornalismo. Assim esta pesquisa se justifica como pioneira: traz um modelo de audiodescrição específico para esse gênero televisivo e mostra suas possibilidades e limites. E qual a importância de trabalhar com a inclusão das pessoas com deficiência visual também por meio da recepção das mensagens dos telejornais? A questão inclui essencialmente o reconhecimento e respeito por esse outro. A deficiência é uma questão de toda a sociedade e incluir é transformar o todo.

\section{O não-lugar da pessoa com deficiência}

Quando discutimos a questão da deficiência o que está em jogo é o tema do outro, da alteridade. O outro é sempre uma exterioridade real, um corpo, uma subjetividade, uma pessoa que pede passagem e quer ser reconhecido como diferente de mim - não um outro de mim - mas igual em dignidade. $\mathrm{O}$ outro pode assumir várias figuras: o pobre, o miserável, a pessoa com deficiência, a mulher, o estrangeiro, o negro, o oprimido, o homossexual, a transexual, a criança, o idoso, entre tantas outras minorias. Toda vez que esse outro mostra-se muito 'diferente', a tendência é assombrarmo-nos. Segue-se, então, a indiferença, o desprezo, o descaso, o esquecimento. Forma-se uma rede de vigilância e punição daqueles enquadrados fora do padrão da normalidade vigente.

Buscamos chamar atenção para esse esquecimento, para esse não-lugar que as pessoas com deficiência ocupam em nossa sociedade. Um não-lugar, segundo Martins (2005, p.4), formado por uma série de barreiras físicas, sociais e culturais que negam seu direitos e sua

\footnotetext{
${ }^{1}$ Sistema oficial do governo brasileiro para depósito de todas as teses e dissertações brasileiras.

${ }^{2}$ Mecanismo de busca que integra as Bibliotecas Digitais de Teses e Dissertações (BDTD) das universidades brasileiras que utilizam o sistema do IBICT.
} 
participação na vida social, cultural e coletiva. Com a inclusão, procura-se a inserção do diferente nos diversos setores da vida em sociedade, com base no entendimento de que todas as pessoas, independente de raça, etnia, orientação sexual, condição física e mental, devem usufruir dos mesmos direitos.

\begin{abstract}
A inclusão é um processo que contribui para a construção de um novo tipo de sociedade através de transformações, pequenas e grandes, nos ambientes físicos espaços internos e externos, equipamentos, aparelhos e utensílios, mobiliário e meios de transporte - e na mentalidade de todas as pessoas (SASSAKI, 1997, p.42).
\end{abstract}

A conquista mais recente no processo inclusivo no Brasil foi a aprovação em junho de 2015 do projeto que instituiu o Estatuto da Pessoa com Deficiência, sendo sancionada em julho a Lei Brasileira de Inclusão (LBI) - Lei 13.146/15 (BRASIL, 2015). Por meio dela, fica assegurado uma série de direitos às pessoas com deficiência em várias áreas de políticas públicas como educação, trabalho, reabilitação, moradia, tecnologia, entre outras.

Peter Freund (2005) reforça que as estruturas espaciais e temporais são importantes para a construção social da deficiência. Para ele, o ambiente não é só onde ocorrem as interações sociais como é o que estrutura tais interações. Esse não é um espaço neutro porque oferece possibilidades e constrangimentos para os corpos. Ele influencia o funcionamento dos corpos. E muitas vezes é o que incapacitam os corpos. Eles são feitos a partir das conexões e encontros com o mundo. Os ambientes de trabalho, os sistemas de trânsito de rua, podem influenciar em consequências incapacitantes, de acordo com Freund. São os responsáveis por estabelecerem a ideia de pessoas capazes ou não. É a própria sociedade, com seus ambientes deficientes, que tira a capacidade do ser humano. Freund reforça que é preciso que as pessoas tenham consciência dos próprios ambientes deficientes, e que assim passem a exigir seus direitos e espaços adaptados.

\footnotetext{
Once people shift focus from their bodies and their capacities, and see such capacities linked to the organisation of the spaces they utilize, their attendant mode of being in space and how they relate to it changes. Resistance then becomes possible (FREUND, 2005, p. 186).
}

Para Freund, quanto mais atividades e experiências fluírem sem problemas, o corpo estará ausente em consciência. Assim, a deficiência passa a ser um mero detalhe. Corpos marginalizados são o que tornam pessoas deficientes.

Aqui abordamos a questão da exclusão da pessoa com deficiência visual no modo de assistir TV, um ambiente, segundo percepção de Freund, deficiente. Como estabelecer as possibilidades do não-ver frente ao poder das imagens e também à influência da televisão numa cultura extremamente audiovisual? Como ter seu direito de assistir televisão garantido? Como buscar e receber informações nos telejornais em igualdade de oportunidades com as demais pessoas? Como fazer valer seu lugar e direitos de cidadão, especificamente seu direito à informação?

O direito à informação, assim, deve ser pensado como o direito que inclui necessariamente as condições necessárias para realizar as escolhas concernentes ao exercício pleno dos direitos. $\mathrm{O}$ direito de cada um ter acesso às melhores condições possíveis para poder formar as próprias preferências particulares, fazer suas 
escolhas e seus julgamentos de modo autônomo (GENTILLI, 1995, p. 160, grifo do autor).

A produção de informação é que torna possível o mundo e o poder político, em particular, visível ao cidadão e permite que ele se situe na sociedade. É, portanto, a comunicação uma das possibilidades para o exercício da cidadania, com a formação ainda de cidadãos críticos, participativos e inseridos em seu meio social. A preocupação essencial aqui está em incluir as pessoas com deficiência visual, garantindo-lhes acesso ao que é exibido na programação da $\mathrm{TV}$, respeitando o direito à informação e como meio de se reconhecerem e serem reconhecidos como cidadãos.

\section{Acessibilidade e a audiodescrição na tv}

A Lei Brasileira da Inclusão garante no artigo 42, inciso II, o acesso das pessoas com deficiência aos programas de televisão. Os recursos de acessibilidade hoje disponíveis na televisão brasileira são a legenda oculta - closed caption; a interpretação em Libras, que é feita em um espaço delimitado na tela - ambos voltados para inclusão das pessoas com deficiência auditiva; e, ainda, a audiodescrição, focada principalmente no público com deficiência visual.

\footnotetext{
O recurso consiste na descrição clara e objetiva de todas as informações que compreendemos visualmente e que não estão contidas nos diálogos, como, por exemplo, expressões faciais e corporais que comuniquem algo, informações sobre o ambiente, figurinos, efeitos especiais, mudanças de tempo e espaço, além da leitura de créditos, títulos e qualquer informação escrita na tela (POZZOBON, G.; POZZOBON, L., 2010).
}

O usuário recebe a informação contida na mensagem ao mesmo tempo em que ela aparece. As descrições acontecem nos espaços entre os diálogos e nas pausas entre as informações sonoras, isto é, ocorre nos "silêncios" das cenas, seja na tela ou no palco. E não interfere nos efeitos musicais e sonoros. Segundo Hysk (apud BRAGA, 2011, p.24-25) nem todas pausas precisam ser preenchidas. Os espectadores também podem sentir o silêncio do filme, quando isso for relevante. Deve-se evitar que a AD sobreponha ao conteúdo original. $\mathrm{O}$ ideal é que exista uma harmonia entre o som inicial e a audiodescrição inserida.

A audiodescrição é considerada uma tradução, mas não entre línguas. Ocorre entre meios semióticos diferentes, do visual para o verbal oral, sendo uma tradução audiovisual intersemiótica. "Trata-se, portanto, de uma narração que é inserida nos espaços em que o texto audiovisual não apresenta elementos acústicos e que descreve aquilo que se vê" (JIMENEZHURTADO, 2007, apud MEDEIROS, 2012, p. 21).

A AD pode ser gravada ou ao vivo. A opção gravada é normalmente usada em filmes, programas de TV (gravados) e obras de arte. E é sempre acompanhada de roteiro. No caso de filmes, além dos personagens, ambientes e ações, ainda são audiodescritos a linguagem da câmera, com enquadramentos, planos, ângulos e os movimentos da câmera em si.

$\mathrm{Na}$ televisão, ocorreram debates para aplicação da audiodescrição no sistema analógico, mas a obrigatoriedade do uso da $\mathrm{AD}$ acabou sendo transferida para a TV digital. 
Por isso, hoje a audiodescrição só está disponível para quem tem TV digital. Somente ela, a audiodescrição, que torna possível a inserção das pessoas com deficiência visual na programação da TV.

\section{Aliança entre telejornalismo e a audiodescrição}

A função básica do telejornal é informar sobre os fatos que são transformados em notícia na tela. Alfredo Vizeu afirma que "os telejornais cumprem uma função de sistematizar, classificar e hierarquizar a realidade. Dessa forma contribuem para uma organização do mundo circundante [...]" (2006, p. 108). Através da presença de apresentadores (as) em estúdio, são veiculados diferentes formatos noticiosos como notas (secas e cobertas ${ }^{3}-$ sem ou com imagens, respectivamente); reportagens; entrevistas e séries de reportagens.

Os telejornais fazem parte do gênero jornalístico por meio do suporte audiovisual. E nesse produto televisivo são as imagens que seduzem o público. É importante lembrar que a televisão funciona a partir da relação texto/imagem, os dois devem "caminhar juntos". "Ou o texto tem a ver com o que está sendo mostrado ou não tem razão de existir, perde a sua função. O papel da palavra é dar apoio à imagem e não brigar com ela" (PATERNOSTRO, 1987, p.50).

O essencial no telejornalismo é que imagem e texto estejam "casados", isto é, um seja o complemento do outro. Como destaca Becker, no telejornal palavra e imagem trabalham unidos "para favorecer a compreensão, mas não basta ver, é preciso que alguém nos diga o que estamos vendo. O texto falado conduz e alinha as imagens, som, ruídos, gráficos e vinhetas ${ }^{4,}$ (BECKER, 2005, p. 71).

Para a elaboração da reportagem, o jornalista televisivo tem que ter sempre às mãos quais as imagens foram feitas para que possa fazer esse casamento entre texto/imagem. Paternostro (Id. Ibid.) aponta que em alguns casos ocorre uma incompatibilidade nessa dinâmica.

Há casos de redundância, quando o texto descreve exatamente o que se vê. Também há ainda casos de paralelismo, quando texto e imagem não se complementam, caminhando lado a lado de forma independente. Há ainda casos de distanciamento, quando texto e imagem não têm absolutamente nada a ver com o outro (PATERNOSTRO, 2006, p.86).

A autora reforça ainda que o texto não deve ser descritivo, não deve explicar o que as imagens estão mostrando. Segundo ela, não é necessário "descrever o que o telespectador já está vendo. É óbvio demais. Além de chato". (Id. Ibid., p. 86). Aqui apontamos uma diferença entre a fala do repórter em uma matéria de TV em relação ao que é feito na audiodescrição. Ao contrário do telejornalismo que a dinâmica texto/imagem deve ser compatível, na $\mathrm{AD}$ a regra fundamental é "descreva o que você vê", o que seria uma redundância em telejornalismo, segundo avaliação de Paternostro.

\footnotetext{
${ }^{3}$ Nota cuja a cabeça (Texto lido pelo (a) apresentador (a) para introduzir a reportagem) é lida pelo apresentador e o texto seguinte é coberto com imagens

${ }^{4}$ Arte breve, podendo ter texto, associada a um trecho musical que identifica emissora, apresentador, programa, quadro etc.
} 
Ainda sobre a reportagem de telejornal quando não há imagens para acompanhar o texto, outros recursos podem ser utilizados, como mapas, selos, desenhos, gráficos, quadros, legendas, fotos, animação, simulação, reconstituição, etc., que irão facilitar a compreensão do que está sendo dito.

Quando existe uma imagem forte à mão ela deve ser ressaltada na reportagem. Em alguns casos, pode ser usado o som ambiente ${ }^{5}$ para dar ênfase a ela. Por exemplo, quando uma bomba é detonada ou há um tiroteio intenso. Ou até mesmo as vozes que ecoam em um protesto. A reportagem utiliza apenas o som ambiente da situação, sem a necessidade de palavras. É o silêncio da fala. Nestes casos, a imagem vale mais do que frases descritivas. Outro caso recorrente de uso do som ambiente ou do sobe som ${ }^{6}$, segundo jargão jornalístico, é em matérias consideradas frias, atemporais (podem ser exibidas em outro dia sem que a informação fique "velha", utilizando o jargão jornalístico). Por exemplo, um VT 7que fale sobre a riqueza do artesanato é uma matéria fria. Normalmente são pautas produzidas e reportagens mais trabalhadas durante a edição e ganham mais brilho por meio do sobe som, unindo a um BG (Background) $)^{8}$ com imagens ricas em detalhes.

As matérias "quentes", por sua vez, são aquelas que devem entrar no telejornal no mesmo dia em que são produzidas. São os chamados factuais, como, por exemplo, casos de acidentes, prisões, desastres, coletivas de imprensa, etc. Essas matérias não recebem tanto "zelo" durante a edição, até mesmo por terem um tempo curto na ilha de edição. Mas também nelas podem ser encontrados os ditos sobe som. Por exemplo, como já citado, a detonação de uma bomba em uma ocorrência dentro de um banco.

A reportagem de TV ainda pode ser de comportamento e de serviço, em sua maioria, ditas matérias frias. "Comportamento" engloba assuntos de cultura, entretenimento, lazer. O uso do BG é recorrente. Ainda há uma edição de imagens mais detalhada, com uso de fusão ${ }^{9}$ e outros recursos de edição. Já as de "serviço" são reportagens que divulgam, como o nome diz, algum tipo de prestação de serviço ou utilidade pública. A produção é mais trabalhosa, mas a edição é simples, sem muitos efeitos e normalmente não há uso de sobe som.

Existem algumas formas de montagem das reportagens. É usual a gravação dos textos por meio de $o f f S^{10}$, associados a passagem ${ }^{11}$ do repórter com sonoras ${ }^{12}$ dos entrevistados. $\mathrm{O}$ repórter aparece uma única vez. Os offs seguem como em uma "costura", emendados com as sonoras e a passagem. Um outro modo de realizar a reportagem é por meio do plano sequência, que é quando o repórter narra o caso e o cinegrafista deriva para o que está sendo comentado. Em geral, não apresenta a estrutura de offs. A "costura" funciona quase como que uma passagem do repórter colada a outra. O material passa a ser um pouco mais descritivo. $\mathrm{O}$ cinegrafista ajuda o repórter a se posicionar e privilegia o melhor ângulo para contar a história.

Além das reportagens e notas secas e cobertas, o telejornalismo pode ser realizado

\footnotetext{
${ }^{5} \mathrm{O}$ mesmo que áudio ambiente - sons do local em que a cena acontece.

${ }^{6}$ Usado com o próprio som ambiente captado na cena ou pode ser usado com fundo musical e imagens da matéria.

${ }^{7}$ Termo substituto de reportagem, matéria.

${ }^{8}$ Som do ambiente ou música de fundo que acompanha a fala do repórter (off).

${ }^{9}$ Recurso de edição. Desaparecimento e aparecimento simultâneo da imagem, que chegam a ficar sobrepostas. Usada em matérias mais elaboradas.

${ }^{10}$ Fala do repórter, sem a sua imagem na tela.

${ }_{11}^{11}$ Gravação feita pelo repórter no local do acontecimento, com informações a serem usadas no meio da matéria.

É o momento em que o repórter aparece na matéria para destacar um aspecto da matéria.

12 É a fala do entrevistado na matéria
} 
com as entrevistas de estúdio, sejam com especialistas, personalidades, grupos culturais e bandas de música. Nesses casos, também há a utilização de sobe som, de encenações e até a demonstração de produtos, como capa de CDs, livros, encartes, entre outros. Tudo acompanhado de uma certa movimentação no estúdio, ainda que isso reflita apenas nas mudanças de câmera, com angulações diferentes dos entrevistados.

Percebe-se, assim, que para assistir TV e às notícias nos telejornais o sentido da visão torna-se preponderante. Temos que as imagens falam por si só, traduzem posturas, condições. Significam. Ganham eficácia ainda maior quando complementam ou são complementadas por um texto. Mas e para o público formado por pessoas com deficiência visual, como essas imagens exibidas nos telejornais não percebidas podem chegar até eles?

\section{Telejornalismo audiodescrito}

Conforme apresentado aqui, a $\mathrm{AD}$ consiste na descrição das informações visuais e acontecem nos espaços entre os diálogos e nas pausas entre as informações sonoras. E a audiodescrição deve evitar sobrepor o conteúdo original. Temos que no telejornalismo, por sua vez, texto e imagem caminham juntos. Apesar de não haver uma descrição da imagem no texto, eles são complementos um do outro.

Benecke (2004 apud SEOANE, ARAÚJO, 2011), audiodescritor profissional que desenvolveu parâmetros para auxiliar no desenvolvimento de roteiros, afirma que deve haver a escolhas de programas apropriados ao citar alguns dos passos para elaboração de roteiros. Os noticiários, no caso, não são indicados. "Alguns programas são muito movimentados e outros possuem falas quase que de forma continua deixando muito pouco tempo para descrições como noticiários e programas de jogos como quiz" (2011, p. 3). Assim, nosso principal questionamento era como elaborar um roteiro de AD nos poucos "silêncios" existentes durante as reportagens e entrevistas de estúdio no telejornal. Mas entendemos que essas brechas existem, ainda que pequenas.

Para perceber os momentos em que, de fato, a audiodescrição pode ser inserida no telejornalismo, tivemos como foco de estudo a AD no MGTV, transmitido de segunda a domingo pela TV Integração, afiliada da Rede Globo em Juiz de Fora, Minas Gerais. A audiodescrição foi realizada em uma matéria de comportamento ${ }^{13}$, aqui denominada como "Diversão e Arte" - nome do quadro ao qual a reportagem faz parte (G1 Zona da Mata, 2015a); e ainda uma entrevista de estúdio - "Estúdio Zona Blue" (G1 Zona da Mata, 2015b), exibidos nos dias 20 e 21 de março de 2015, respectivamente. O vídeo foi retirado do site G1 que reproduz as reportagens exibidas pela TV Integração. O roteiro foi elaborado por essa pesquisadora e com consultoria de Cristiana Cerchiari, professora do curso na especialização em audiodescriação pela UFJF em que essa pesquisadora concluiu em 2015. Cristiana é revisora de roteiros de audiodescrição desde 2009. O trabalho também foi enviado para a coordenadora do curso, a professora e audiodescritora Lívia Motta. A locução é da também audiodescritora Patrícia Almeida, com edição e mixagem do áudio feito por essa pesquisadora.

A audiodescrição foi elaborada a partir das observações desta pesquisadora em trechos onde era necessária a audiodescrição e possível de ser acrescentada, de acordo com o tempo

\footnotetext{
${ }^{13}$ Engloba assuntos de cultura, entretenimento, lazer.
} 
de "silêncio" disponível, priorizando descrever aquilo que se via e que merecia de tradução para as pessoas com deficiência visual. Segundo SEOANE, ARAÚJO (2011, p.44) "audiodescrever qualquer cena por completo é uma tarefa impossível. O audiodescritor precisa fazer escolhas e tomar decisões que reduzam ao máximo as perdas sofridas pelo deficiente visual em relação ao entendimento do filme".

O VT "Diversão e Arte" falam sobre a comemoração do Saint Patrick's Day em Juiz de Fora, com apresentação de uma banda da cidade em uma casa de show. De acordo com a reportagem, a festa incluiria, além de música, os pratos típicos da data que é originalmente celebrada na Irlanda. Esse era o último VT do telejornal. Assim, continuamos a realizar a AD até o encerramento do mesmo, após a colocação da ficha técnica do programa na tela. O vídeo apresentado neste trabalho inclui esse encerramento, totalizando 6'09'.

A audiodescrição foi acrescentada antes mesmo da cabeça ${ }^{14}$ da matéria, com a apresentação da vinheta do quadro "Diversão e Arte", exibido às sextas-feiras no MGTV $1^{\text {a }}$ edição. Após a fala da apresentadora, o VT começa. Logo no início há um sobe som de 45 segundos com a banda tocando uma música. Neste ponto foram acrescentadas falas de AD. A passagem da repórter também recebe $\mathrm{AD}$, dizendo o nome dela, assim como todas as sonoras dos entrevistados. No caso da passagem da repórter foi necessária antecipação da AD para não sobrepor com o áudio que vinha adiante.

Ao longo do VT, outros momentos de sobe som receberam audiodescrição, assim como algumas cenas que mereciam a explicação do que estava ocorrendo. A sobreposição do áudio foi breve, aproveitando momentos de repetição de palavras, como, por exemplo, "bem, humm, ehhh...". No fim do VT, há outro sobe som de 47 segundos que também foi audiodescrito.

A cena seguinte é a despedida da apresentadora e após aparece a imagem da rua onde fica a emissora. A cena foi audiodescrita. Em seguida, "sobe a ficha" com o nome dos responsáveis pela elaboração do telejornal, assim como surge a logomarca da emissora. Todos esses elementos visuais verbais precisavam e foram audioescritos.

Neste VT, em alguns momentos foi priorizado o som apresentado em detrimento das descrições. A tentativa foi de evitar uma audiodescrição contínua, permitindo momentos de silêncio para que a pessoa com deficiência visual também pudesse apreciar o som que estava sendo tocado, havendo harmonia entre a $\mathrm{AD}$, a imagem e trilha sonora. Receberam audiodescrição as principais ações que acontecem ao longo da reportagem e as inserções de entrevistados e da repórter, além dos elementos visuais verbais, como da ficha técnica ao fim.

Já o segundo VT selecionado para a inserção da audiodescrição - "Estúdio Zona Blue" - tem a apresentação da banda juiz-forana Zona Blue no estúdio do MGTV, totalizando 4'14". O grupo iria fazer uma apresentação naquela noite em uma casa de show da cidade com sucessos de Cazuza, Frejat e Barão Vermelho. O VT selecionado surge após a volta do intervalo comercial. Portanto, há no início do VT aqui apresentado a vinheta de passagem ${ }^{15}$ do telejornal, que recebeu audiodescrição. A cena seguinte é da apresentadora Érica Salazar, que anuncia a presença no estúdio dos músicos, totalizando cinco homens. Quatro estão sentados, tocando instrumentos, e o vocalista, Ricardo Capra, que é quem conversa ao longo da apresentação com Érica Salazar está de pé atrás da banda. Parte da composição desta cena foi audiodescrita aos 22 segundos de VT, com pequena sobreposição à fala de Érica. Os

\footnotetext{
${ }^{14}$ Texto lido pelo (a) apresentador (a) para introduzir a reportagem.

${ }^{15}$ Música, associada a uma arte/logomarca, que identifica um programa no início e fim de um bloco ou uma transmissão.
} 
instrumentos que eles tocam foi audiodescrito mais adiante, quando havia um tempo maior para inserção da AD.

A seguir, há um bate-papo entre a apresentadora e o vocalista. A AD é inserida quando ele responde à pergunta da apresentadora, anunciando quem é esse entrevistado. Aos 1'34" os músicos começam a tocar, com sobe som por 1'04". Logo no início a câmera está focada no vocalista e a $\mathrm{AD}$ traz as características físicas de Ricardo Capra. Em seguinte, a audiodescrição é sobre os instrumentos que os músicos tocam. Há um jogo de imagens no estúdio, com a troca de câmeras e de ângulos. A apresentadora Érica está em muitos deles, ao lado da banda acompanhando a apresentação. Por isso, recebe $\mathrm{AD}$ também com suas características físicas e o local que está no estúdio.

Adiante, a música cessa e retorna o bate-papo, sempre com o vocalista. Em 3'15" há novo sobe som. A AD é aplicada em apenas dois momentos, com uma aproximação de câmera no vocalista e outra que descreve detalhes do estúdio que aparece ao fundo enquanto os músicos tocam.

Para a inserção da audiodescrição mais uma vez foi priorizado o som apresentado em detrimento das descrições. A cena e ação principal foram audiodescritas e o essencial, a partir de então, foi permitir a apreciação do som. Receberam audiodescrição os elementos visuais não verbais, como os espaciais (localização espacial dos personagens), os atributos físicos da apresentadora e do vocalista, além das principais ações que acontecem ao longo da exibição da reportagem, seja por meio do movimento de câmera, seja pela composição do cenário. Houve ainda a inserção de AD para identificar quem era o entrevistado que conversava com a apresentadora.

Percebemos com esses exemplos como a audiodescrição por ser utilizada no telejornalismo. No caso de sobe som, por exemplo, inserido na reportagem, a imagem deve ser descrita e há espaço para isso. Para nós, videntes, e conforme é ensinado aos estudantes de Jornalismo, a imagem vale mais do que frases descritivas nesses exemplos de "sobe sons". Mas para o cego isto não é compreensível. Em matérias quentes, em que os offs acontecem sem muitas pausas, podem ocorrer a utilização de sobe som e é aí que entra a audiodescrição. As matérias frias, por sua vez, como vimos são mais trabalhadas, com uso recorrente de BG e provavelmente de "silêncios". Nesses materiais o uso da AD será mais usual e também necessário.

No caso das passagens dos repórteres, a AD deverá sobrepor rapidamente o material original para informar à pessoa com deficiência visual que naquele momento existe uma aparição de quem está conduzindo a reportagem. Essa sobreposição deve ser evitada, mas pode ser utilizada quando necessário. Isso deve ser aplicado, inclusive, quando há a utilização do plano sequência.

Apontamos ainda a necessidade de se repensar a forma como são utilizados os recursos imagéticos como mapas, gráficos, quadros, principalmente. Muitas vezes a elaboração do texto não é igual ao que está sendo apresentado na imagem. Fica subentendida a leitura complementar, principalmente quando relacionada a dados. Verificamos que nestes casos não há espaço para a realização da audiodescrição. Mas entendemos que é preciso que haja a reformulação desses textos, com orientações no meio acadêmico e nas redações, para que os cegos e pessoas com baixa visão também possam estar incluídos e recebam essa informação completa. Acrescentamos ainda que os próprios textos podem ser um pouco mais descritivos, com inserção de poucas palavras, que já trazem significado à pessoa com deficiência visual. Por exemplo, quando o texto diz "a imagem que você vê agora" pode ser acrescentada de "a imagem do incêndio que você vê agora". Apenas a palavra "incêndio" 
trouxe uma informação a mais para as pessoas com deficiência visual.

Outra forma de inserção da audiodescrição no telejornalismo é em relação às entrevistas de estúdio. A movimentação que acontece neste momento deve ser descrita para a pessoas cega ou com baixa visão. Por exemplo, se o entrevistado usa paletó ou algum traje mais sofisticado, quantas pessoas da banda estão no estúdio, quais instrumentos tocam, se os artistas estão caracterizados, entre outros. Quando há o sobe som enquanto uma banda se apresenta, informar se a câmera focaliza o rosto de alguém ou faz um plano geral do ambiente. Isso tudo também deve ser audiodescrito. Lembrando que aqui utilizamos a entrevista de estúdio com AD gravada somente para que sirva como exemplo da possibilidade de uso do recurso. Mas a sugestão é de que essa audiodescrição seja simultânea, ao vivo. A audiodescrição de matérias frias que, em geral, são elaboradas e editadas com antecedência, pode ser feita gravada. Mas entendemos que aquelas matérias que são factuais, muitas das vezes chegando no horário final de fechamento do telejornal, a $\mathrm{AD}$ deve ser feita ao vivo, seguindo o roteiro de reportagem apresentado pela equipe de reportagem à edição. Assim como nas entrevistas ou outros eventos realizados ao vivo no estúdio, a audiodescrição deve ser simultânera. Inclusive nesses casos o acesso ao espelho do jornal, em que se encontram as perguntas prévias para o estúdio, são fundamentais.

\section{CONSIDERAÇÕES FINAIS}

Como vimos, a audiodescrição é o recurso de acessibilidade que poderá colaborar para tornar ambientes e produtos mais acessíveis. A AD permite que as pessoas com deficiência visual possam assistir à televisão de modo mais agradável; permite a sensação de igualdade por poderem comentar com pessoas sem deficiência os programas de TV e, principalmente, as notícias dos telejornais, que são foco deste estudo; além de trazer a independência e inclusão social. Por isso, entendemos que o telejornal não pode estar excluído desse processo.

Em AD não há possibilidade de descrever toda a informação imagética de uma cena em tão curtos intervalos de tempo, como ocorre no telejornalismo. Assim, o audiodescritor deve entender como esse gênero televisivo se configura para que a audiodescrição possa ser inserida. Devem ser selecionados apenas os elementos mais relevantes para a construção da narrativa, de modo que também não a prejudique. Aqui conseguimos apresentar as brechas para que ocorra a inserção de $\mathrm{AD}$ no telejornalismo, seja em reportagens ou em entrevistas de estúdio. Assim, concluímos que há momentos diversos ao longo do telejornal em que a inserção da audiodescrição é possível, seja gravada ou ao vivo.

Além disso, a pesquisa permite discutir a forma de ensino de telejornalismo, que como parte da produção audiovisual, pouco ou nada se recorda daqueles que não enxergam. Uma reflexão sobre o modo de se fazer jornalismo para TV também pode ser considerada uma consequência do trabalho aqui apresentado, trazendo novas perspectivas até mesmo para o ensino do telejornalismo nas universidades. Entendemos que é preciso repensar a máxima que texto de TV não pode ser descritivo e que quando se descreve exatamente o que se vê o texto para TV torna-se redundante. Afinal, a preocupação do jornalista é com a estética da TV ou fazer com que a informação de interesse público chegue ao maior número de pessoas, o que inclui o telespectador com deficiência visual? Essa discussão nos parece ser bem necessária e urgente. Pequenas mudanças na construção do texto podem deixar a informação mais clara para todos e minimiza o problema da existência de poucos "silêncios" no telejornalismo para 
inserção da AD. Entretanto, é certo que a descrição das imagens por meio da AD precisa ser realizada também no telejornalismo para que as pessoas com deficiência visual se sintam incluídas na cultura audiovisual televisiva.

\section{REFERÊNCIAS}

BECKER, Beatriz. A linguagem do telejornal: um estudo da cobertura dos 500 Anos do Descobrimento do Brasil. Rio de Janeiro: E-papers, 2005.

BRAGA, Klistenes Bastos. Cinema acessível para pessoas com deficiência visual: a audiodescrição de 'O grão de Petrus Cariry'. 01/03/2011.144 f. Dissertação (Mestrado) Programa de Pós-Graduação em Linguística aplicada, Universidade Estadual do Ceará. Fortaleza, Ceará, 2011.

BRASIL. Portaria $n^{\circ}$ 188, de 24 de março de 2010. Sobre os recursos de acessibilidade para pessoas com deficiência, na programação veiculada nos serviços de radiodifusão de sons e imagens e de retransmissão de televisão. Disponível em http://www.anatel.gov.br/legislacao/normas-do-mc/443-portaria-188. Acesso em: <12 fev. 2019>.

Lei $n^{\circ}$ 13.146, de 06 de julho de 2015. Institui a Lei Brasileira de Inclusão da Pessoa com Deficiência (Estatuto da Pessoa com Deficiência). Disponível em: http://www.planalto.gov.br/ccivil_03/_Ato2015-2018/2015/Lei/L13146.htm. Acesso em: <12 fev. 2019>.

FREUND, Peter. Bodies, disability and spaces: the social model and disabling spatial organizations. In: FRASER, Miriam; GRECO, Monica. The body: a reader. London: Routledge, 2005, p. 182-186.

GENTILLI, Victor. Democracia de massas: cidadania e informação. Trabalho apresentado como requisito para obtenção de título de Mestre em Ciências da Comunicação. Escola de Comunicação e Artes, Universidade de São Paulo, São Paulo, 1995.

G1. Diversão e arte: dia de São Patrício é comemorado em Juiz de Fora. G1 Zona da Mata, Juiz de Fora, março 2015a. Disponível em: http://g1.globo.com/mg/zona-da-mata/mgtv1edicao/videos/t/edicoes/v/diversao-e-arte-dia-de-sao-patricio-e-comemorado-em-juiz-defora/4049901/. Acesso em: <10 jan. de 2019>. 
G1. Banda Zona Blue canta ao vivo no estúdio do MGTV. In: G1 Zona da Mata, Juiz de Fora, março 2015b Disponível em: http://g1.globo.com/mg/zona-da-mata/mgtv1edicao/videos/t/edicoes/v/banda-zona-blue-canta-ao-vivo-no-estudio-do-mgtv/4052475/.

Acesso em: $<10$ jan. de 2019>.

MARTINS, B. D. G. S. Políticas sociais da deficiência: exclusões perpetuadas. 2005. http://www.ces.uc.pt/publicacoes/oficina/228/228.pdf. Acesso em: <ago. de 2016>.

MEDEIROS, Francisca Rafaela Bezerra. Elementos para a microestrutura de um glossário semitrilíngue dos termos da audiodescrição. 01/03/2012. 131 f. Dissertação (Mestrado) Programa de Pós-Graduação em Linguística Aplicada, Universidade Estadual do Ceará. Fortaleza, Ceará, 2012.

PATERNOSTRO, Vera Iris. $O$ texto na $T V$ : manual de telejornalismo. São Paulo: Brasiliense, 2006.

POZZOBON, Graciela; POZZOBON, Lara. O que é audiodescrição?. Site audiodescrição. Disponível em: http://audiodescricao.com.br/ad/o-que-eaudiodescricao/. Acesso em: <25 mar. de 2016>.

POZZOBON, Lara. Blind Tube: conceito, audiodescrição e perspectivas. In: MOTTA, Lívia M.V.M; FILHO, Paulo Romeu (orgs.). Audiodescrição: Transformando imagens em palavras. Secretaria de Estado dos Direitos da Pessoa com Deficiência. Estado de São Paulo, 2010, p.107-116.

SCORALICK, Kelly. Por uma TV acessivel: a audiodescrição e as pessoas com deficiência visual. 2017. Tese (Doutorado) - Programa de Pós-Graduação em Comunicação, Universidade Federal do Rio de Janeiro. Rio de Janeiro, RJ, 2017.

SEOANE, Alexandra Frazão; ARAÚJO, Vera Lúcia Santiago. A audiodescrição do filme Corisco e Dadá. In: Cultura \& Tradução. João Pessoa, v.1, n.1, 2011.

VIZEU, Alfredo Eurico. O lado oculto do telejornalismo. Florianópolis: Calandra, 2006.

Recebido em: 09/10/2019

Aprovado em: 10/12/2019 